\title{
Application of Thomas Model to Determine the Capacity of Bintaro Fruit Shell Adsorbent
}

\author{
Timothy Blessing ${ }^{1}$, Okik Hendriyanto ${ }^{1 *}$, Euis Nurul Hidayah ${ }^{1}$, Anis Artyani ${ }^{2}$ \\ ${ }^{1}$ Department of Environmental Engineering, Universitas Pembangunan Nasional "Veteran" Surabaya, East Java, \\ Indonesia \\ ${ }^{2}$ Department of Environmental Engineering, Institut Teknologi Nasional Malang, East Java, Indonesia
}

*Corresponding author:

E-mail: okikhc@upnjatim.ac.id

\begin{abstract}
The increase in the electroplating industry resulted in a large number of heavy metal wastes that are harmful to the environment, for example, hexavalent chromium waste. The Bintaro which contains cellulose is considered as a potential adsorbent to remove heavy metals. Therefore, a comparative study on the adsorption capacity of continuous adsorption was carried out in reducing the concentration of heavy metal $\mathrm{Cr}^{+}$in electroplating wastewater. The characterization itself can be done by testing the moisture content and ash content and SEM testing. The study of the adsorption capacity in a continuous process is generally carried out with Thomas modeling, where this research is carried out by a continuous adsorption process with variations in the adsorbent mass of 50 grams, 100 grams, 150 grams, 200 grams, and 250 grams. The best results were obtained to remove $\mathrm{Cr}^{+}$metal which was $94.4 \%$ in the Bintaro shell adsorbent type with a mass of 250 grams. The continuous adsorption process obtained the highest Thomas constant (Kth) value and the highest adsorption capacity (qo), namely using Bintaro shell activated carbon with a mass of 250 grams with an absorbance capacity value of $0.443 \mathrm{mg} / \mathrm{g}$. The results showed that the activated carbon of Bintaro shell showed that they were quite effective as adsorbents in the adsorption process to remove heavy metal $\mathrm{Cr}^{+}$
\end{abstract}

Keywords: Bintaro shell, Cr6 $6^{+}$metal, Thomas modeling

\section{Introduction}

Chromium metal is a metal that pollutes the environment. Chrome hexavalent or $\mathrm{Cr}$ (VI) is carcinogenic, if consumed by humans it can cause poisoning and vital organ disorders such as nervous disorders and cancer (Nurhasni et al., 2010). Therefore, the magnitude of the impact on the environment, treatment is needed before the waste is disposed of environment. Efforts to reduce heavy metals from wastewater have been done a lot several methods such as ion exchange, sedimentation, coagulation-flocculation, and electrochemical process, but the adsorption method is still one of the methods mostly used for the removal of heavy metal ions due to adsorption has high absorption ability, high efficiency and high-cost low (Nasruddin et al., 2017).

The adsorption method in the process requires adsorbent as an absorbent agent. The adsorbents that are often used come from agricultural waste. Some agricultural waste can be used as an alternative to adsorbent including apple skin, peanut shell, coconut shell, and skin cassava which is able to adsorb heavy metals. According to Hasrianti (2012) shows that the cassava peel can absorb Cr (VI) ions as much as $12.82 \mathrm{mg} / \mathrm{g}$. Meanwhile, tamarind seeds can be used as activated carbon to adsorb $\mathrm{Cr}$ (VI) and showed $21.71 \%$ chromium absorbed from the tannery waste. The results of these studies indicate that it is waste agriculture containing cellulose can be further processed as adsorbent. Bintaro fruit shell contains high cellulose so that it has the potential to be used as an alternative for making adsorbents. An adsorbent with bintaro fruit shells can degrade $\mathrm{Mn}$ ions by $86.94 \%$ with variations in the concentration

How to cite:

Blessing, T., Hendriyanto, O., Hidayah, E. N., \& Artyanti, A. (2020). Application of thomas model to determine the capacity of bintaro fruit shell adsorbent. $1^{\text {st }}$ International Conference Eco- Innovation in Science, Engineering, and Technology. NST Proceedings. pages 107-111. doi: 10.11594/ nstp.2020.0516 
of H3PO4 activator in raw water (Aisyahlika et al., 2018), Other research is by degrading $\mathrm{Cr}^{+}$ions by $99 \%$ with variations type of activator (Rosalina, 2016)

The use of activation can also be used as a method of expanding pores adsorbent in increasing the capacity of the bio-adsorbent trap. While the model is can be used to determine the adsorption capacity of the bio-sorbent in the system continuous data based on the influent and effluent concentration, velocity flow in the flow process, as well as the volume of solution passed to the column adsorbent.

Adsorption is a complex process whose performance is supported by many variables. The outlet concentration of the adsorption column is an important parameter in designing a process. Predicting the concentration of the outlet is not easy. The maximum filling capacity of the distillation column is required in the design. Thomas's model is used to meet these needs. Based on the description above, a comparative study was conducted on the adsorbent capacity of Bintaro fruit shells to the removal of heavy metal ions hexavalent chrome or $\mathrm{Cr}(\mathrm{VI})$ in waste electroplating with a fixed bed column system.

\section{Research Method \\ Preparation stage}

This preparation stage includes several processes, from forming charcoal, to changing its physical characteristics to common (commercial) charcoal. Bintaro fruit shells and durian fruit skins that have gone through an open burning process (carbonization with a temperature of $200^{\circ} \mathrm{C}-400^{\circ} \mathrm{C}$ ) are washed and dried under the sun then sieved with a \pm 100 size sieve to obtain charcoal particles with a size \pm 100 mesh.

\section{Activation stage}

If the charcoal formation stage has been successful, then the next step is the activation stage of charcoal into activated carbon so that it can be used as an adsorbent in the adsorption process:

1. Successful charcoal will then be mashed and then sieved with a mechanical sieve.

2. 25 grams of sifted charcoal is taken to be immersed in $250 \mathrm{~mL}$ of $\mathrm{NaOH}$ solution for 24 hours, then filtered with filter paper, then washed with distilled water to neutral $\mathrm{pH}$.

3. After that, the activated charcoal is dried in an oven at $120^{\circ} \mathrm{C}$ for 30 minutes.

4. After activation, SEM tests will be carried out before and after.

\section{Main research}

The research was conducted using an adsorption column. Column adsorption is a column cylinder which generally has a fairly large length and diameter ratio. Bintaro fruit shell adsorbent is inserted into the column and is kept from carrying flow by installing supports at the base of the column. Adsorption is carried out with the waste stream to be processed according to a predetermined flow rate, which is 20 $\mathrm{ml} / \mathrm{min}$ through the Bintaro fruit shell adsorbent media. The adsorbent mass used was 50 grams, 100 grams, 150 grams, 200 grams, and 250 grams. The research was conducted with a down-flow system.

During this process, there will be the absorption of ions in the adsorbent with ions in the electroplating waste. The adsorbent part that comes in the first contact with the waste will first reach equilibrium. When the adsorbent has reached equilibrium, the next part of the bed will be filled with ionic waste. Therefore the adsorption process in the column is a process that depends on the time and mass of the adsorbent. If the bed portion is saturated, the adsorbate concentration at the bed output will increase. If the bintaro fruit shell adsorbent is completely saturated, a release will occur, namely, the release of adsorbed substances so that the concentration of pollutants in the effluent will be the same or close to the concentration in the influent.

\section{Results and Discussion}

\section{The effect of mass variation of activated carbon on removal $\mathrm{Cr}^{+}$}

In this study, a comparison was made between two types of adsorbents, namely activated carbon from Bintaro shells with five mass variations of activated carbon, namely; 50 grams, 100 grams, 150 grams, 200 grams, and 250 grams. Meanwhile, the adsorbent size and waste discharge became fixed 
variables, namely 100 mesh and $20 \mathrm{ml} /$ minute, respectively. The mass effect of each type of activated carbon can be determined by comparing the percent removal to the sampling time of each mass variation.

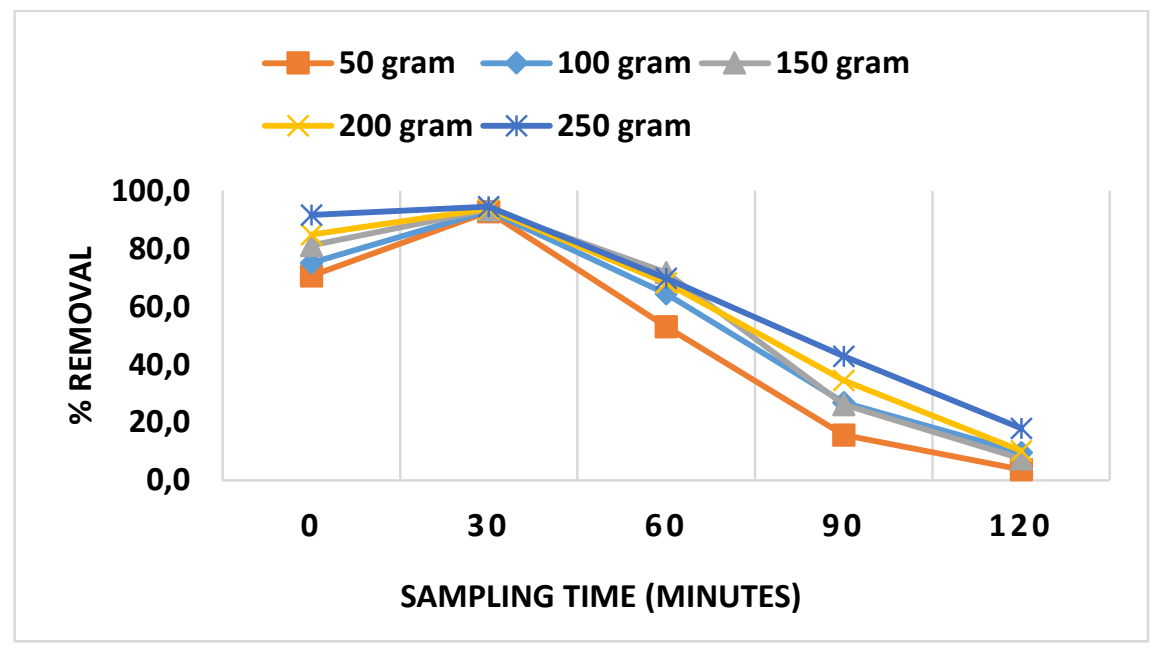

Figure 1. The relation of sampling time to percent removal with various adsorbent masses

The first sampling time was obtained after the electroplating liquid waste was right out of the adsorption column and the retrieval was continued in 30 minutes for 120 minutes to obtain a sampling time of 5 sampling times. The graph above describes the use of Bintaro shell activated carbon with different adsorbent masses. The optimal hexavalent chromium removal results for Bintaro shell activated carbon was obtained with a mass of 250 grams, namely $94.5 \% \mathrm{Cr} 6+$ allowance. The optimum removal occurred at the 2 nd sampling time, namely at 30 minutes. This removal shows that the more adsorbent mass, the more active sites that can bind the adsorbate. The greater the discharge or flow rate, the faster the absorption time, which causes the adsorption time in the column to be shorter, and the mass transfer zone time also shorter (Erawati \& Fernando, 2018).

At the contact time of 60 minutes to 120 minutes, the removal of hexavalent chromium has decreased, this is because the adsorbent undergoes a desorption process where desorption is a process of releasing ions or molecules that have bound to the active group on the adsorbent (Hasni et al., 2015).

\section{Determination of adsorption capacity with thomas modeling}

In this study, the kinetics of the adsorption system that occurs in fixed-bed columns were analyzed using the Thomas Model which is one of the most commonly used column performance theory models. The formula used is:

$$
\operatorname{Ln}\left[\frac{C o}{C_{t}}-1\right]=\frac{K_{t h} q_{0} x}{Q}-K_{t h} C_{0} t
$$

Information:

$\mathrm{Co}=$ influent concentration $(\mathrm{mg} / \mathrm{L})$

$\mathrm{Ct}=$ effluent concentration $(\mathrm{mg} / \mathrm{L})$

$\mathrm{KTh}=$ constant adsorption rate $(\mathrm{L} / \mathrm{mg} / \mathrm{min})$

$\mathrm{X}=$ mass of adsorbent (gr)

qo $=$ absorption capacity $(\mathrm{mg} / \mathrm{g})$

$\mathrm{Q}=$ water flow rate $(\mathrm{L} / \mathrm{min})$

$\mathrm{t}=$ Sampling time (minutes) 
To calculate the adsorption capacity using Thomas's modeling, it is necessary to complement with linear regression calculations $(y=a x+b)$. The KTh and qo values are determined from the slope and intercept of the linear regression curve $\ln (\mathrm{Ct} / \mathrm{Co}-1)$ with respect to time. The Thomas modeling regression graph for two types of adsorbents can be seen in Fig 2. The KTh and q0 values are determined from the slope and intercept on the linear line plot, namely $\ln ((\mathrm{Co} / \mathrm{Ct})-1)$ against the sampling time $(\mathrm{t})$.

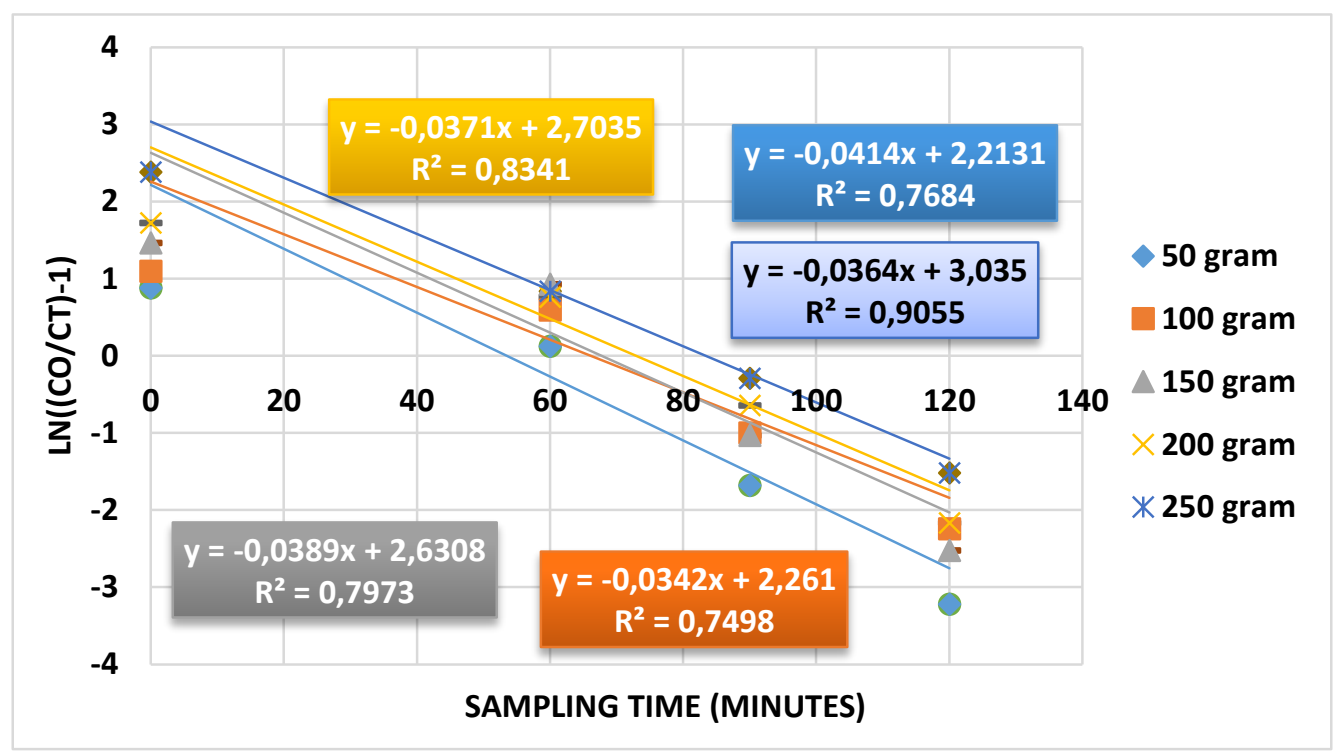

Figure 2. Thomas modelling grap

Table 1. Parameters of the thomas equation model in various experiments

\begin{tabular}{cccccc}
\hline Variation & $\begin{array}{c}\text { Co } \\
(\mathbf{m g} / \mathbf{L})\end{array}$ & $\begin{array}{c}\text { Mass of ad- } \\
\text { sorben }(\mathbf{G r})\end{array}$ & $\begin{array}{c}\boldsymbol{K}_{\boldsymbol{t h}} \\
(\mathbf{m L} \mathbf{m g} / \mathbf{m i n})\end{array}$ & $\begin{array}{c}\boldsymbol{q}_{\boldsymbol{o}} \\
(\mathbf{m g} / \mathbf{g})\end{array}$ & $\boldsymbol{R}^{\mathbf{2}}$ \\
\hline 1 & 1.329 & 50 & 0.035 & 0.263 & 0.7853 \\
2 & 1.329 & 100 & 0.032 & 0.3 & 0.7878 \\
3 & 1.329 & 150 & 0.029 & 0.359 & 0.7973 \\
4 & 1.329 & 200 & 0.025 & 0.406 & 0.8289 \\
5 & 1.329 & 250 & 0.027 & 0.443 & 0.9055 \\
\hline
\end{tabular}

The value of the coefficient of determination $\left(\mathrm{R}^{2}\right)$ obtained from the experimental results is greater than 0.75 indicating that external and internal diffusion does not affect the adsorption process that occurs (Asnawati, 2017), so the Thomas Model is suitable to describe the kinetics of the adsorption column that occurs.

The Thomas constant and adsorption capacity data were obtained from the Thomas equation with the ratio of adsorbent types. To get the Kth and qo constant values, it can be seen through the slope and intercept values of the equations shown in Figures 2 Based on these equations, the constant values are 
shown in Table 1. Where the Thomas constant obtained is inversely proportional to the adsorption capacity of each adsorbent. This is following the Thomas equation which has been applied in this study which shows that the adsorption capacity is an inverse comparison with the resulting thomas capacity.

In the results of the calculation of the Thomas equation, it was found that the highest adsorption capacity in the absorption of $\mathrm{Cr}^{+}$at a mass of 250 grams was $0.443 \mathrm{mg} / \mathrm{g}$. This means that 1 gram of activated carbon can absorb (qo) the uptake of pollutants in mg. The purpose of finding qo in Thomas's modeling is to find out how much pollutants are absorbed against 1 gram of adsorbent.

\section{Conclusion}

The results of the study can be concluded that:

1. Bintaro fruit shell could remove $\mathrm{Cr}(\mathrm{VI})$ about $94,4 \%$, it is conjectured that bintaro fruit shell could be used as an alternative bio-sorbent for removing heavy metals.

2. The optimum mass adsorbent for removing $\mathrm{Cr}$ (VI) was 250 grams, it is indicated that a higher mass of adsorbent provides a higher surface area, then resulted in a higher removal.

3. Thomas model obtained the value of adsorbtion flowrate constant (Kth) $=0,027 \mathrm{~L} / \mathrm{mg} / \mathrm{min}$ and adsorbtion capacity $(\mathrm{qo}=0.44 \mathrm{mg} / \mathrm{g})$

\section{Acknowledgment}

Praise be to God Almighty for giving His grace and guidance so that this journal can be completed properly. And we also thank Mrs. Euis Nurul Hidayah ST., MT., Ph.D. because she is the one who always helps and provides direction. As well as colleagues who are good at working together and giving encouragement.

\section{References}

Aisyahlika, Z., \& Firdaus, S. L., \& Elvia, R. (2018). Kapasitas adsorpsi arang aktif cangkang bintaro (Cerbera odollam) terhadap zat warna sintetis reactive red-120 dan reactive blue-198. Alotrop, 2(2),148-155.

Erawati, E., \& Fernando, A. (2018). Pengaruh jenis aktivator dan ukuran karbon aktif terhadap pembuatan adsorbent dari serbik gergaji kayu sengon (Paraserianthes Falcataria). Jurnal Integrasi Proses, 2(7), 58.

Hasni, H., Arahman, N., \& Mulyati, S. (2015). Penyisihan Fe dalam air tanah menggunakan zeolite alam banda aceh teraktivasi. Jurnal rekayasa kimia \& lingkungan,10(3), 11-16. doi: 10.23955/rkl.v10i3.3069

Hasrianti. (2012). Adsorpsi Ion Cd2+ Dan Cr6+ pada limbah cair menggunakan kulit singkong. Jurnal Universitas Stuttgart, 1(5),1-24

Nasruddin,, Rosnelly, M., Mulana, C., \& Farid. (2017). Adsorpsi Ion Logam Cr (VI) dengan menggunakan Karbon Aktif dari Tempurung Kemiri (Aleurites Moluccana). Jurnal Ilmiah Kebencanaan Pascasarjana Unsyiah Kuala 4(4),117-125.

Nurhasni, Hendrawati, N., Saniyyah, H., \& Fathurohman, N. (2010). Penyerapan ion logam Cd Dan Cr dalam air limbah menggunakan sekam padi. Jurnal Kimia Valensi, 1, 310-319.

Rosalina (2016). Buah Bintaro Terhadap Daya Serap Logam Berat. Jurnal Biopropal Industri, 1(7), 35-45 